Chapter Title: Flying Blind in Brussels: How National Officials Do European Business

Without Political Steering

Chapter Author(s): Karin Geuijen and Paul 't Hart

Book Title: Working for Policy

Book Editor(s): Hal K. Colebatch, Robert Hoppe, Mirko Noordegraaf

Published by: Amsterdam University Press. (2010)

Stable URL: https://www.jstor.org/stable/j.ctt46n2ww.16

JSTOR is a not-for-profit service that helps scholars, researchers, and students discover, use, and build upon a wide range of content in a trusted digital archive. We use information technology and tools to increase productivity and facilitate new forms of scholarship. For more information about JSTOR, please contact support@jstor.org.

Your use of the JSTOR archive indicates your acceptance of the Terms \& Conditions of Use, available at https://about.jstor.org/terms

This book is licensed under a Creative Commons Attribution-NonCommercialNoDerivatives 4.0 International License (CC BY-NC-ND 4.0). To view a copy of this license, visit https://creativecommons.org/licenses/by-nc-nd/4.0/.

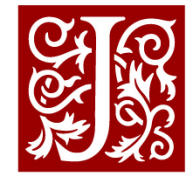

Amsterdam University Press is collaborating with JSTOR to digitize, preserve and extend access to Working for Policy 


\title{
$9 \quad$ Flying Blind in Brussels: How National Officials Do European Business Without Political Steering
}

\author{
Karin Geuijen and Paul 't Hart
}

Flying blind: A policy bureaucrat's predicament

Most democratic governments have a well-established norm concerning 'politics' and 'bureaucracy' in the executive branch: ministers set goals and assign priorities whereas civil servants advise them and strive to implement ministerial and cabinet decisions. Decades of research into the relations between politics and administration in numerous countries have shown that this norm is alive and well, but, at the same time, it does not accurately describe practice at either the national or local government levels (Savoie 2003; Peters 200I; 't Hart and Wille 2006). Politicians cannot keep track of, let alone explicitly direct, everything their vast, complex, highly specialized bureaucracies are involved in. Hence many officials, even those working in governmental departments that are relatively close to the political executives, spend a lot of time and energy anticipating, second-guessing or actively seeking 'a steer' from their superiors, who, in turn, will seek to obtain ministerial guidance (Page and Jenkins 2005). The further away from the political centre civil servants operate, the more fictitious the idea becomes that their work is dictated by explicit political decisions or directions.

Many civil servants in service delivery agencies, particularly 'street-level bureaucrats' have learned to cope with this, to the extent that they would regard political 'micromanagement' of their day-to-day work processes as highly undesirable interference in their professional domain (Maynard-Moody and Musheno 2003). But, for departmental civil servants, acting without a clear sense of political direction amounts to 'flying blind.' What should they be engaged in when politicians don't know, don't care, or don't lead? What coping mechanisms have they developed for dealing with this normatively anomalous situation? And what does this mean for the shaping of public policy and for the nature of the politics-administration nexus within the executive branch?

These are the questions that inspired this chapter. To explore it empirically, we have chosen what we regard as a clear-cut case of civil servants working in a 'political leadership vacuum': the policy work engaged in by national 
officials who participate in processes of international governance in 'low politics,' 'technocratic' areas. We shall present an in-depth study of Dutch officials who are involved in cooperative European policing efforts. Below, we briefly introduce the case, its relevance for our present purposes, and the research methods used to study it. Then we go on to examine how European police cooperation takes shape. We do so first by offering a thick description' of how a particular aspect of police cooperation, namely the management and protection of sensitive data on national citizens and entities is processed. The case vignette illustrates how difficult it is to fashion, articulate, let alone defend, a coherent 'national position' on it. We then go on to let Dutch officials who 'do' European police cooperation speak about their experiences, focusing in particular on how they experience and cope with handling an issue area where clear, politically sanctioned policy compasses are lacking. We conclude by discussing the implications of 'professional bricolage' replacing 'political responsiveness' as the main principle of civil service practices in this kind of setting.

\section{Eurocrats in transnational networks: Serving who or what?}

Politics and bureaucracy have shifted to new locations. The well-known and mostly well-entrenched national arena is no longer the only one in which ministers and departmental civil servants work. As Slaughter (2004) has observed, international cooperation has intensified and international regimes have proliferated in recent decades, both in number and in scope and depth. As a result, transnational networks of civil servants have come into being who breathe life into these international regimes and the bodies that epitomize them.

The civil servants who populate these networks have to juggle multiple identities and roles. On the one hand, they are policy experts, specialized in certain, often rather technical, areas, exchanging information, cooperating on enforcing regulation, and jointly constructing laws, regulations and practices that they as experts all believe will work. On the other hand, these civil servants are not free-floating intelligensia. They participate in these networks with a mandate from their national ministries or agencies to represent the national government.

One of the new sites where these transnational networks emerge is within the European Union. Although agreement among experts about figures turns out to be surprisingly difficult to obtain, there is little question that in recent decades a significant portion of hitherto national regulation and policy development is now being produced in European arenas. These European- 
ized policy-making processes involve an intricate and often complex interplay between actors and institutions at the (sub)national and EU level. Europeanized policy arenas have developed distinctive rules, norms and practices that govern this interplay (Richardson 2006). Knowing how to exploit these distinct features is a crucial condition for any actor - be it a national ministry, a trans-national pressure group or a multinational firm - seeking to wield influence over European policy-making processes (Van Schendelen 2003).

A sophisticated policy management capacity at the European level is something that all member states seek to achieve. They know that in order to safeguard their national interests, they need their representatives to understand and manipulate the peculiar agenda-setting mechanisms, institutional rhythms, opportunity structures and veto points of European policy making. It is what ministers whose portfolios are in highly Europeanized policy domains expect their civil servants to deliver. These expectations are not always met: studies in various countries show that knowledge, institutional capacity and effective coordination at the national level are often patchy and variable (Hanf and Soetendorp 1998; Kassim et al. 2000; Laegreid et al. 2004; Geuijen et al. 2008).

Building up this type of coherent policy management capacity is difficult, partly because the European project as such places pressures on one of its chief agents: the civil services of the member states. When operating in EU arenas, national civil servants are not acting solely as national representatives; they are also encouraged to engage as technical experts. Eurocrats, defined here as national civil servants for whom dealing with and acting in EU bodies is their main task, have to juggle two (or sometimes three) identities: as 'servants of the (national) crown,' as 'members of professional fraternities that transcend national boundaries and interests,' and every now and then as 'supranationals' or 'Europeans.'

How much of each role guides their beliefs and actions depends on the kinds of settings in which they operate. There is, for example, a world of difference between national civil servants participating in expert Commission committees dealing with the implementation of EU regulations and those who attend Council working parties; the former fosters a 'postnational' identity as a member of a profession whereas the latter's position and procedures conduces toward a role conception as national representative (Beyers and Trondal 2004; LaRue 2006; Thedvall 2006; Trondal 2002). From Beyers (2005). However, we also know that Belgian civil servants who participated in Council working parties and who felt that they had received unclear instructions, experienced poor domestic coordination and policy preparation, and had a relatively strongly developed supranational role conception. 
So, Eurocrats qua national bureaucrats are supposed to take their cues from the political-administrative hierarchy, which employs them; Eurocrats qua experts are driven to cooperate with colleagues to solve common or transboundary problems and thus foster a 'European project' in their professional realm. Given these conflicting imperatives, it becomes essential for their political (and hierarchical) superiors to provide direction and constrain inclinations to 'go native' in Brussels. Yet, for a variety of reasons ministers (and their political staffers) often fail to do so. When this happens, whom do Eurocrats take their cues from? We answer this question by looking at a particular case: Dutch Eurocrats working in the field of European police cooperation. ${ }^{1}$ It is part of a larger study in which we wanted to find out which civil servants in the Netherlands were involved in European policy processes, how they approached their European tasks, what they actually did, and how their beliefs and practices were shaped by the organizations in which they worked (Geuijen et al. 2008).

We examined these issues using five different, complementary methods of data collection. We studied the relevant reports, documents and academic literature. We incorporated several questions into a large survey on job characteristics, satisfaction and public sector motivation administered by the Dutch Ministry of the Interior (the so-called POMO survey). The survey was conducted in the first months of 2006 and was completed by 4502 civil servants working in central government organizations. It gave us a unique, quantitative assessment of the number and type of civil servants involved in EU decision making, as well as their judgment of the organizational aspects of their tasks. Thirdly, we conducted structured, thematic interviews on police cooperation with 2I middle-ranking and top officials from the relevant ministries, executive agencies and the Dutch Permanent Representation in Brussels. We asked them about their experiences in 'doing' European policymaking (and, to a lesser extent, policy implementation) in The Hague, in Brussels, and anywhere else that their jobs took them. Fourthly, we engaged in observation of the Europe-related work routines of officials in different parts of the Dutch police, the Ministry of the Interior, the Ministry of Justice. Finally, we conducted five expert meetings with middle-ranking and top-level officials throughout the Dutch government, in order to check on the broader salience of these initial findings, and further deepen our insights on what it means to be, and organize, national 'Eurocrats.' A total of 27 officials participated in these sessions, which lasted 2.5 hours each. They were taped and transcribed.

Before turning to the case study, it may be helpful to first get some more information about the organizational setting they work in and on the mandate Dutch civil servants receive when going to Brussels. Depending on how much 
time their officials spend on average on EU-related activities, we classified the ministries into three categories: Eurocratic bulwarks, Eurocratic runners-up, and national champions (or Eurocratic laggards). Eurocratic bulwarks (e.g., the Ministries of Agriculture, and Economic Affairs) have more than $50 \% \mathrm{Eu}$ ropeanized civil servants, Eurocratic runners-up (e.g., the Ministries of Social Affairs, and of Finance) have between $30 \%$ and $40 \%$ Europeanized civil servants, and Eurocratic laggards have well below 30\%. The Ministry of Justice is a Eurocratic laggard with no more than $17 \%$ of its civil servants involved in EU-related work, spending about one hour a week on this task (median time). European police cooperation is one of the EU-related tasks that officials are responsible for at the Ministry of Justice. This task is taken up by a small number of specialized civil servants. Large parts of police work and criminal policy are (or seem) firmly domestic in scope.

Table 1 Response by civil servants working in ministries with different levels of Europeanization to the statement 'When I participate in EU-level meetings, I receive a clear negotiation mandate.'

\begin{tabular}{llllll}
\hline & $\begin{array}{l}\text { Degree of } \\
\text { Europeanization }\end{array}$ & Disagree & Neutral & Agree & $\mathrm{N}$ \\
\hline Mandate & Low & $26 \%$ & $38 \%$ & $36 \%$ & 47 \\
& Moderate & $28 \%$ & $52 \%$ & $21 \%$ & 239 \\
& High & $22 \%$ & $36 \%$ & $42 \%$ & 176 \\
\hline
\end{tabular}

Source: Geuijen, 't Hart, Princen and Yesilkagit (2008: 47)

We asked civil servants in our survey to what extent they would agree with the following statement: 'When I participate in EU-level meetings, I receive a clear negotiation mandate.' As the table above shows, it turned out that there were some differences in how mandates were handled between ministries with a high, moderate or low level of Europeanization. Only a bit more than one third of these civil servants who participate in EU-related tasks say their mandate is clear, and about a quarter thinks it is not clear at all. The rest do not agree or disagree. The really interesting question is how civil servants who do not have a clear mandate handle this situation when they are in Brussels. To put it bluntly: How do they know what to do and say? 


\section{Governing without politicians: Inside a Eurocratic outpost}

I am here to represent the Netherlands, and my colleagues back home sometimes have difficulties in appreciating that. They do the individual ministries' bidding. Their arena is about pulling and hauling between ministries. Here the arena is about pulling and hauling between countries (An official at the Dutch Permanent Representation to the EU).

Since the expansion of the EU to 25 (and now 27) member states, cooperation in the sensitive field of justice and home affairs is hampered by concerns about sovereignty and lack of trust among member states. Some years ago, the Dutch Minister of Justice, Piet-Hein Donner, launched a rather bold plan to develop European cooperation towards a common European legal space. This plan received little support amongst the member states of the European Union, and nothing similar has replaced it, so there is no European vision for increasingly 'post-national' legal cooperation. Nor is there a Dutch one, with the responsibility for policing historically split between two ministries, which have at best maintained a 'complicated' relationship because of it. National politicians - Dutch or otherwise - perhaps conscious of the strong public sentiments attached to policing which make it a political 'hot potato,' and operating in the open, young, not yet highly institutionalized field of Justice and Home Affairs, are evidently either unwilling or unable to produce a coherent post-national policy on police cooperation. Let us see how civil servants in this field cope with this fact.

\section{The case of data availability}

Data availability is one of many topics on the agenda of European Justice and Home Affairs institutions. The transnational sharing of information on anything - people, communication data, (stolen) vehicles, arms, explosives, poison, money - that might lead to a threat to safety and security in member states is widely considered vital to all EU governments. But plans to facilitate this information sharing have aroused serious privacy concerns, fears about a loss of sovereignty in this key domain of state activity, as well as charges that these measures may undermine the rule of law. Different national viewpoints on data sharing have surfaced repeatedly in the preparations for the European Council of JHA Ministers, and, as such, this case provides us with a poignant view on how Dutch Eurocrats deal with such a topic. Below we report on our observations and interviews in a low-level, working party and a high-level committee where this issue was processed. 


\section{A low-level committee: The Working Party on Police Cooperation}

On 25 January 2006, a meeting was held at the Dutch Ministry of the Interior in The Hague. Its purpose was to prepare the Dutch position on a proposal from the Austrian Presidency for a European Council decision on improving police cooperation between member states of the European Union. A major part of the proposal concerned procedures for improving transnational information sharing among police forces. The leader of the Dutch delegation was supposed to present the Dutch position on the proposal the day after, during a meeting of the Police Cooperation Working Party, one of the countless committees that prepare and help implement European policies and programs. The delegation leader, who was a senior official from the Interior Ministry, chaired the discussion. Four of his counterparts at the Ministry of Justice (the Ministries of Interior and Justice share responsibility for Dutch policing policy) also attended the meeting. There were also two representatives from the Dutch National Police, both of whom were veterans who had seen their last active duty years ago.

These were the people effectively making Dutch policy on European police cooperation: a small group of specialized civil servants. They worked within a ministry and within the National Police Force, neither of which, for the most part, were particularly interested in this topic. But the EU Working Party on Police Cooperation exists and every member state has to be present at its meetings and present the national position on the items to be discussed. At the preparatory meeting, the Dutch Eurocrats constructed the national position. But they had to do so without having a clear political position, and without a clear political lead, because top civil servants are not inclined to construct a position either. As one mid-level civil servant, the head of this unit, told us: 'We stick to the last known political position on the issue. Sometimes we are against a proposal because we have always been against it even if no one knows exactly why'

During the preparatory meeting, the participants discussed an Austrian proposal. There was much talk about what seemed to be technical aspects: could the Dutch police departments meet the requirements envisaged in the proposal, would they have to adjust their information systems, and could one expect other countries' police forces to do likewise? From this it became clear that for them a major goal of bargaining was that national systems did not need to be adjusted. The relevant treaties, which might bear upon the measures proposed, were presented. No mention was made of ministerial or parliamentary decisions or opinions on the subject. There was no real debate about anything on the agenda: the participants seemed to agree, and the 
'Dutch position' simply emerged from that consensus. It involved 'wheeling and dealing' and the coordination - in fact, the piling up - of interests. The result seems to be a fuzzy position. One of the policemen present did not seem to be fully aware of the procedural 'nitty-gritty' of European policymaking, asking about the role that the European Parliament plays in all of this. With thinly veiled disdain, one of the civil servants at the Justice Department suggested he attend 'a course on European matters' that would be taught soon.

The next day, the meeting of the Police Cooperation Working Party took place in Brussels. A full-day affair, it was set in the same enormous conference room where the Justice and Home Affairs (JHA) Council of Ministers meets, the eventual 'end station' for all these preparatory meetings. All of the participants were allowed to speak in their native language as interpreters translated to and from all of the official languages of the member states, and everyone wore headphones throughout the meeting. Cameras were an essential part of the interaction process because everyone had a screen on their desk on which the speaker appeared in close up, for everyone to read his/her facial expressions. There were also several enormous screens hanging from the ceiling on which the same images appeared. The Dutch delegation consisted of three members. There was the delegation leader, sitting at the conference table, with an official from the Dutch Permanent Representation to the EU sitting next to him, and the third member sitting behind them.

The most striking part of the meeting ritual was that participants were referred to not by their own name, but by the names of their countries. The delegations were seated at a huge oval table, behind shield with the countries' names. A participant who wished to make a statement had to put his shield on its side. The chairperson would then grant him permission to speak, saying things like 'The Netherlands, the floor is yours,' and would close the interjection with words like 'Thank you, the Netherlands.' There was little contact between members of the various delegations. Everybody was polite but controlled, and stuck strictly to the accepted format. There were few informal greetings or casual asides. The Dutch delegation leader did leave his lunch before the others to meet with the Irish delegation on a project the Irish proposed, which partly overlapped with a Dutch proposal that was also up for discussion.

Previous studies of council working groups portrayed the meeting process in comparable terms: they are diplomatic events rather than technocratic meetings of experts who share a common professional background and a sense of urgency' to solve operational problems. Our observations and interviews strongly suggest that they are still first and foremost about countries talking to countries, through their representatives. The multinational perspective is reinforced by the meeting's rituals. 
During the meeting, the various parts of the proposal on the agenda were discussed in depth. It was a long day with arcane technical matters receiving sustained attention. The key proposal under scrutiny had been discussed before in other Council working groups like ENFOPOL, ENFOCUSTOM, CRIMORG and COMIX. Remarkably, hardly anyone ever referred to these discussions in other forums; it appeared as if the participants had not been briefed about them. One of our informants characterized it as an example of the so-called third pillar's 'organized anarchy'.

The Austrian chairperson meanwhile tried to reach an agreement on as many parts of the proposal as possible. She had a few private discussions with her assistants and members of the Secretariat of the Council and would then propose differently worded parts of the proposal. This meeting was about weighing, shaping and bending words until everybody agreed. The goal was clearly to get an agreement on as many issues as possible within the so-called technical setting of the lower-level working party. At the end of the discussion, the chairperson gave a short summary of the suggested changes to the proposal, on which she assumed there was general agreement. She also summed up issues for which no consensus-inducing words had been found. The proposal was then forwarded to the Comité de l'Article Trente-Six (CATS), a coordinating committee of senior civil servants. CATS would focus on those parts of the proposal on which no consensus had been reached, i.e., what were now referred to as the more 'political' parts of the proposal as opposed to what would be defined as being the more 'technical' parts since civil servants were able to reach consensus on them (cf. Fouilleux et al. 2005). After CATS had discussed, perhaps modified and signed off on it, the resulting proposal would be sent further up the European policymaking hierarchy, to the Comité de Représentants Permanents (COREPER), the committee of the member states' ambassadors to the European Union. Once approved there, the proposal would finally come up for a political decision in the JHA Council of Ministers.

\section{A high-level committee: CATS}

An official from the Ministry of Justice and formerly from the Permanent Representation in Brussels who participated in the preparation of the CATS committee pointed out that he was acutely aware of the disjointed nature of the working group system. He thought the European Commission actually exploited the 'organized anarchy' in the third pillar by offering its proposals to different working groups, hoping that at least one of these channels will serve 
to lead this proposal up to the Council. However, the leader of the Dutch delegation to the CATS committee disagreed. He did not feel the Commission was playing the system. He thought it would be a great improvement if all of the proposals to the Council in the third pillar were made by the Commission. This would at least bring some consistency to this messily disjointed terrain. Currently there was none. His chief concern with the current system was that ad hoc political pressures led high-level actors in CATS and JHA to choose hasty, patchy proposals coming 'from nowhere.' According to him, 'the culture of the European arena is such that any decision is better than no decision at all.' He deplored the adhocracy this tended to produce, citing instances in which some decisions clearly conflicted with prior CATS decisions or decisions made by another forum in the JHA field. He summed it up poignantly: 'In this policy process, lack of decisiveness is less of a problem than lack of coordination.'

The Dutch delegation leader also observed another important form of pressure on the CATS committee process. At the end of the day, all of the participants in CATS are accountable to their own national bureaucratic constituencies. Hence, he and his counterparts from the other countries vet each proposal put before them with one key criterion in mind: is there something in it for 'us'? The bottom line of the CATS meetings is that the participants are first and foremost national civil servants, and feel compelled to act as such - or face uncomfortable questions from colleagues and superiors back home.

The CATS delegation members identify themselves first and foremost as national civil servants, just like the participants in the Working Party on Police Cooperation described earlier. They seemed to know each other better than their lower-level counterparts did, addressing each other (by way of the chairperson) by their first names during the meeting. The Dutch delegation leader said that he would prefer acting more like a genuine 'European,' siding with the common good rather than Dutch national interests as his reference point for assessing proposals and taking positions. Unfortunately, he said, his colleagues in The Hague, as well as his counterparts in forums such as CATS are overwhelmingly locked into their national perspectives. They seem primarily intent on preserving their existing national policies, procedures and judicial systems. He welcomed the pressure put on his colleagues by the Foreign Ministry and the Permanent Representation, 'who regularly argue that something has to happen, some improvements have to be made. If it wasn't for that, everybody would simply lie back and wait.'

The CATS delegation leader considered himself lucky to at least have an 'EU-minded' minister at the time. This gave him a lot of support in urging his colleagues to 'get on with it.' The Dutch Minister of Justice had made crime 
fighting his top priority and was very aware of its European dimension. The CATS delegation leader pointed out that this provided him with opportunities. 'Within the Netherlands, you often act as the representative of an EU position: you overact your European allegiance in order to create some room to maneuver. You do the reverse in Brussels, by saying: "I cannot possibly take this back to my superiors at home."

Navigating and re-interpreting mandates was part of the job. He was very aware that the national position that he was supposed to represent had been only constructed by himself and his colleagues, not a cast-in-stone translation of clearly expressed ministerial preferences. So, he took it with a grain of salt and tweaked it depending on the setting in which he was operating. He made on-the-spot decisions about what to say when and to whom, even though he in fact did have written instructions that had been discussed in some detail and agreed upon in the preparatory meeting before the CATS meeting.

\section{Getting by without direction: Eurocrats reflect}

There seem to be at least two different reasons for a lack of political steering towards a future of European cooperation in the field of police activities, at least in the Dutch case. The first is that political superiors are simply not interested. The other is that political superiors may take an active interest but feel they lack the power to make a difference because relevant parties at both the national and European level are not interested in pursuing cooperative solutions to joint problems. One civil servant reflected on how the JHA Council of Ministers operates: 'The ministers don't say: "this is how we're going to do it," they just cannot come to an agreement. In practice, they send a proposal back to the working parties with some vague directions for "technical" revisions. But it just went from these working parties to the Council of ministers so that they could make a political decision.' A member of the Permanent Representation confirms this point of view: "There is very little vision regarding what direction to take when it comes to police cooperation. The general idea is to try to avoid inconveniences due to anything new. However, it would be so much better to try to benefit from new initiatives.' As a result, civil servants are, to some extent, left in the dark. In response, they generally choose to stick to existing national systems and practices as their point of reference. A colleague from the Ministry of Interior hints at why civil servants seem to act the way they do: As long as there is no clear political vision about a certain theme, there isn't much vision that is developed among civil servants either.'

At the national level, relevant Dutch actors are consistently unable to arrive at a unified national viewpoint on the European future in police cooperation. 
A former Dutch CATS delegation leader who subsequently became delegation leader for the Management Board of Europol sighed: 'Now that it is clear that there isn't going to be a positive attitude toward further cooperation at either the national level or at the European level, it makes no sense to develop a substantive vision on the European future on cooperation regarding police and judicial affairs ... There is no national position on this, neither on the formal level, nor anything that is internalized by civil servants.' But with or without a coherent political position on the issue, Dutch Eurocrats have to anticipate and respond to ongoing moves at the EU-level policy game on police cooperation. They have to attend the meetings that are organized by the presidency, with each presidency hoping to achieve some tangible results.

And so they have to be creative in inferring a position where there really is none. For example, a senior Eurocrat at the Ministry of Justice argued that there is, in fact, a Dutch national position on European police cooperation, only it can't be found anywhere on paper. It is more of an established mindset, which he sums up as follows: 'It is clear what we do not want: no violation of the principle of territoriality [national sovereignty on criminal justice affairs], no minimum standards for punishment. But it is not very clear what we do want ... We do want a clear division between first and third pillar affairs, we want to push back the influence of the European Commission.' He also referred to the plan a former Dutch Minister of Justice proposed some three years ago, which was a common European legal space for criminal justice. This plan was shot down by a broad coalition of other member states. It was proposed again to the Cabinet of JHA Commissioner Frattini after some revision, but here they felt that 'the time wasn't ripe for this yet.'

With these efforts having come to naught, the Dutch attitude toward European police and judicial cooperation has turned predominantly negative. Optimizing one's own performance and making pragmatic trans-border deals with neighboring countries are now the priority. Police ministries have reached an anti-Europe Eurocratic consensus: 'We want to be bothered as little as possible by Europe.'

There are exceptions to this general picture. More explicit political steering does occur from time to time, primarily on particularly sensitive issues such as drugs policy and organized crime where ministers and top civil servants have intense discussions concerning their positions. Moreover, during the preparations for the Dutch Presidency of the EU, not only were ministers personally involved in a much wider range of issues, but many toplevel civil servants in the ministries were also interested in various European agendas. Time and energy were devoted to making the period of the Dutch presidency a success, and it was: in the JHA field, The Hague Programme ${ }^{3}$ 
was often mentioned as one of the European successes of the Dutch civil service.

The activist mood and the perceived need to act in unison at the EU level to be successful, however, quickly evaporated after the Dutch presidency ended. The system simply returned to 'normal.' During our fieldwork period (20056 ), we noticed a decided lack of political steering most of the time concerning most of the police cooperation issues agenda. So, what did the involved civil servants do in this case? How did they cope? How did they know what to do?

One Eurocrat observed that council working party civil servants like himself simply decided what the national position on a certain theme would be. They did not receive written mandates. 'It is often difficult to prepare a position. We receive the relevant documents for meetings very late, generally only a few days before a meeting is scheduled. A revised version is often received just before a meeting is about to begin. There is seldom any time left to discuss things. And it is difficult to predict what will even be on the agenda.' Another civil servant said she often wrote her own instructions the day before a working party meeting. 'I mail some ideas to our representative at the Permanent Representation, then we call each other in the evening and then I write it all down.' At the technical level, there were often no interdepartmental negotiations either: individual civil servant acted as they saw fit. They used some of the policy documents on related themes to read up on earlier decisions, recommendations or directives they needed to keep in mind when formulating their own instructions.

They might even tell the delegation superior about their positions and the outcomes of a working party meeting as the proposal ascends the ladder to the level of the COREPER, where a minister has little discretion left for steering the proceedings. Although this situation provided them with a significant amount of scope to influence policy, most of the Dutch Eurocrats we spoke to were not very satisfied with the current situation. One of them observed that 'it does not reflect what the relationship between a minister and the civil servants should be ... Ministers should ultimately have the first and last word. They should set the parameters to be developed at the level of the working parties. But, in practice, this is not how things proceed, sometimes it actually works the other way around.'

Our data availability case shows that issues do go through preparatory meetings in which a national position is discussed. But how do civil servant operate in these types of situations? It depends. In the preparatory meeting for the working party on police cooperation we saw that a national position was constructed via a series of discussions between departmental civil servants and Eurocrat representatives from the national police (not 
representative of the entire Dutch police force). One of the problems with these practices is that there is simply too much bureau-political wheeling and dealing. This produces fuzzy positions that accumulate and do not integrate or prioritize various parochial views and issues. Consensus tends to be achieved at the lowest common denominator with many insisting that new EU policies should interfere as little as possible with existing national systems. The civil servants involved in this process were not particularly happy with this 'freedom,' because they felt that they lacked strategic ministerial support.

Dutch civil servants were responsible for constructing their own national position even in situations such as the CATS delegation in which there was an active and interested minister willing to make a phone call to a colleague from another member state to expedite the decision-making process or generate support for the Dutch position.

These observations stand in stark contrast to another policy sector we studied in depth for another, larger study (Geuijen et al. 2008). Veterinary policy, an old and deeply Europeanized first pillar field, is an policy area where the civil servants can depend on well-developed and clear political choices made by the minister and the policies established by the department's management board. The Ministry of Agriculture and Fisheries' administrative routines are geared towards incorporating and facilitating EU policy-making processes. Here civil servants are sometimes also required to write their own instructions, but they always have clear policy markers, which establish the limits of their discretion. In Brussels they can be trusted to keep the 'national position' in mind. Moreover, veterinary policy is part of a close-knit expert community in which officials have considerable leeway in determining their own priorities and positions. Veterinary experts deliberate with one another at the departmental level, at the level of the 'field' - i.e., industry, veterinarians, laboratories, etc. - and also at the regional, national, and EU levels. They accept each other as experts, sharing a similar educational and professional background.

The expertise needed to discuss the issues at the committee and working party levels is sometimes so specialized that even their heads of department may not fully comprehend the technical complexities. As a result, officials receive only a certain limited amount of steering leeway from the department's political and administrative leadership. But they know what to say and do because they perform within an agreed-upon policy framework, which means that they can be trusted by their superiors as well as by their (transnational) colleagues. 


\section{Responsiveness or bricolage?}

Doing business on European police cooperation is not an easy task for Dutch Eurocrats. A cogent policy framework and the attendant set of institutions have yet to be developed. In fact, it is not clear that the EU as such will be the main forum for police cooperation; there are many smaller regional, ad-hoc, issue-based groups (such as police forces and judicial agencies) who are already collaborating. Moreover, as we have seen, Eurocrats - at least the Dutch ones - are more often than not left without any specific political guidance during the preparations for deliberations with their colleagues from other member states. One proviso is in order, however. The field of our case study is still a relatively new European policy area. So it is perhaps not so surprising that the policy processes, politicians, and civil servants are still finding their way in these loosely related, multi-level networks through which EU governance evolves, particularly in the third pillar where the European Commission's role is very limited in the intergovernmental model. ${ }^{4}$

In this study, we have tried to show how the setting in which Eurocrats operate forces Dutch civil servants in the field of police cooperation to act in certain ways. There are a number of crucial aspects to this scenario. One, neither Dutch political leaders nor civil servants were very inclined to strive for an increase in European cooperation in this field. Instead, they preferred to focus on 'what is in it for us' in the short run and to cling to their sovereignty in this field in the long run. Thus, Dutch civil servants are not always provided with a clear mandate other than 'we don't want ...' Another point is that national representatives in general do not approve of European Commission efforts to steer the bargaining processes or propose new policies of its own accord. Another aspect is that whichever nation has the presidency at any point usually seeks tangible results during its presidential term, rather than focusing on what expert would call a 'high-quality agreement.' All this is done within a regulated rhythm of meetings within which the national positions are expected to be presented and bargained. This results in a 'messy' process without any clear sense of direction (Ekengren 2002).

Civil servants have to learn to cope with this situation. In national settings they probably have no problem adjusting to changing circumstances because policy processes usually have some political steering. However, in an EU setting, meetings are scheduled and have to be attended and national positions have to be satisfactorily represented, even though there may be no clear declared national position. Civil servants become part of this ongoing 'machine.' They have no choice in this respect - they are obligated to participate. 
We have attempted to show how civil servants in this setting cobble together an understanding of the situation and establish possible courses of action. LéviStrauss's concept of 'bricolage' may be an interesting concept for better understanding the logic of this process. Lévi-Strauss constructed a comparison between the bricoleur and the engineer. The engineer invents new concepts, whereas the bricoleur perceives his universe of instruments as finite. The rules of the bricoleur are to always make do with 'whatever is at hand,' in other words, make something out of one's limited resources. His resources or 'material' are heterogeneous because they bear no direct relation to the current project, or indeed to any particular project, but are the contingent result of earlier occasions and actions. A bricoleur can rely upon an available set of tools and materials and choose certain materials for the problem at hand (Lévi-Strauss 1962:28-29).

The point of bricolage is making the most out of what is at hand to accomplish a specific goal. The resources on hand consist of the accumulation of previous manipulations and one's experience and knowledge in the context of a specific goal, which influence the process. The items in the set are not limited to a single use or a single meaning, but their properties limit their options. Eurocrats are often required to act like bricoleurs because their goal is to construct a national position to enter European negotiations with based on limited resources and input. They are forced to adopt resources from the national setting (with variable degrees of political steering from ministers and control by parliament) and to a Europeanized setting. In this new setting, civil servants do not act as policy experts with clear instructions and ministerial guidance, striving for transnational epistemic consensus. Instead, they construct their own national position on a theme that will be discussed in Brussels. They have an intuitive 'antenna' for this, ensuring they don't go too far, and act both 'effectively' and 'appropriately' (March and Olsen 1989) in these less-institutionalized, unregulated fields.

They piece together several resources in this context: (inter)departmental bargains among civil servants; meetings with experts from the field; policy documents on related subjects; decisions taken earlier in other forums, and recognized political positions taken on related subjects (by a minister, or opposition parties in parliament). They attempt to come up with a suitable position despite contradictory signals, which includes the positions of various political and administrative leaders, their colleagues, the European working parties, etc. Some of them may be more concerned with not doing the wrong thing, to protect their jobs. Others, who are less risk-averse, may try to stretch the limits of possibility, which may end up being accepted by the various stakeholders. All in all, professional bricolage seems to fairly accurately describe 'public service responsiveness to political direction' as a key modus operandi among these Eurocrats. 
The civil servants in this process seemingly move seamlessly between acting as a unit or as a department civil servant involved in intra- or interdepartmental agency politics, as a domain expert involved in developing a professionally sound position, and as a 'classic' civil servant serving his superiors and the hierarchy in general. Once they join the European Union arenas, the dominant identity of these civil servants again undergoes a metamorphosis. Although they are aware of the bricolage process, they are expected to perform as national representatives who articulate and defend the national position vis-à-vis national representatives from other member states and Commission civil servants. However, this last dominant identity continues to show traces of other identities related to one's unit, department, profession or government when the delegation leader re-interprets the 'national position' in the process of intergovernmental bargaining that produces Council policies.

We have attempted to show that Dutch Eurocrats who operate in areas with low levels of political (or hierarchical) political steering identify themselves as national representatives, not as experts or supranationals. This observation differs from what Beyers (2005) found in his study of Belgian civil servants participating in Council working groups who experienced their instructions as weak. These civil servants were inclined to adopt a somewhat more supranational attitude. Why were our findings different in this study of Dutch civil servants in the field of police cooperation? This might be better understood if we take note of the setting in which they operate.

The problem these civil servants face in the field of European police cooperation is that, at the national as well as at the European level, there is no political will to develop a coherent perspective towards greater supranational cooperation. In the absence of a larger European vision, they have no real opportunity to identify with some kind of European project. This leaves them with no alternative but to identify with their nation. They learn to cope with a situation that finds them working in a setting, which requires them to act as national representatives, by constructing the national position that they subsequently continue to represent. In this way their dominant identity as a national civil servant can be maintained.

\section{Conclusion}

In this chapter we presented a case study of 'goal-less' policy work, of national public servants improvising, inventing and interpreting political mandates as they take part in transnational policy networks. Our study portrays a situation of structured improvisation: all of the involved players know that there 
is no sheet music, no conductor, but they have a general understanding of the music they are supposed to produce and of the roles they are expected to play in this production. The Eurocrats we studied had mastered this art of improvisation to perfection. But that does not detract from the problems of this style of policymaking and the significant amount of discretion they wield in making it work. Who or what do they represent? In the absence of political or strategic managerial guidance, how do they know they are serving the public interest'? How are their actions controlled and accounted for? The Eurocratic policy work we observed may be admirable in its professionalism and for its ability to produce pragmatic, jointly constructed solutions for that 'work,' but its practices barely contribute to allaying the misgivings that European citizens continue to harbor about the fundamentally technocratic nature of large swathes of EU policymaking.

\section{Notes}

I Formally the Dutch national government's EU coordination mechanisms have been scrutinized repeatedly, and their strengths and weaknesses have been clearly articulated (Andeweg and Soetendorp 200I; Raad voor het Openbaar Bestuur 2004; De Zwaan 2005). In this study, we regard the Europeanization of national policymaking not just as a coordination challenge but as an emerging, differentiated set of political and professional practices that participants in European policy processes need to master in order to be effective (Heritier et al. 200I). Europeanization, in this sense, has been much less researched in the Netherlands (Schout 1998; Sie Dhian Ho and Van Keulen 2004) than in some other countries (Smith 2000; 200I; Jacobson, Laegreid \& Pedersen 2004; Baetens and Bursens 2004a; 2004b).

2 The main characteristic of the so-called third pillar is its intergovernmental structure.

3 The Hague Programme is the agenda for 2005-20 Io in the JHA field. It was adopted at the end of the Dutch presidency in November 2004.

4 For an analysis of various forms of committee governance cf. Egeberg, Schaeffer and Trondal (2003).

\section{References}

Baetens, M., and Bursens, P. (2004a). 'De Europeanisering van Bestuurlijke Structuren.' [The Europeanisation of Administrative Structures: Coordination and Implementation of European Agricultural and Environmental Policy in Flanders]. In G. Bouckaert (ed.), Vlaanderen en/in Europa: Om- 
gaan met de Unie en Vergelijkend Leren [Flanders and/in Europe: Dealing with the Union and Comparative Learning] (pp. 183-219). SBOV Jaarboek 2004, Leuven: Die Keune.

Baetens, M., and Bursens, P. (2004b).'De Europeanisering van de Bestuurlijke Cultuur.' [The Europeanisation of the Administrative Culture: European Opinions and Attention of Flemish Civil Servants and Politicians.] In G. Bouckaert (ed.), Vlaanderen en/in Europa: Omgaan met de Unie en Vergelijkend Leren [Flanders and/in Europe: Dealing with the Union and Comparative Learning.] (pp. 221-245). SBOV Jaarboek 2004, Leuven: Die Keune.

Beyers, J. (2005). 'Multiple Embeddedness and Socialization in Europe: The Case of Council Officials.' International Organization 59(4), 899-936.

Beyers, J., and Trondal, J. (2004). 'How Nation States 'Hit' Europe: Ambiguity and Representation in the European Union.' West European Politics 27(5), 919-942.

De Zwaan, J. (2005). De EZ Coördinatie van BZ: Goed, Beter, Best. [The EZ Coördination of BZ: Good, Better, Best.] Unpublished advisory report. The Hague: Ministry of Foreign Affairs.

Egeberg, M., Schaeffer, G.G. and Trondal, J. (2003). 'The Many Faces of EU Committee Governance.' West European Politics 26(2), 19-40.

Ekengren, M. (2002). The Time of European Governance. Manchester: Manchester University Press.

Fouilleux, E., De Maillard, J., and. Smith, A. (2005).'Technical or Political? The Working Groups of the EU Council of Ministers.' Journal of European Public Policy 12(4), 609-623.

Geuijen, K.,' 't Hart, P., Princen, S., and Yesilkagit, K. (2008). The New Eurocrats: National Civil Servants in EU Policy-making. Amsterdam: Amsterdam University Press.

Hanf, K., and Soetendorp, B. (eds.). (1998). Adapting to European Integration: Small States and the European Union. London and New York: Longman.

Hart, P. 't, and Wille, A. (2006). 'Politicians and Bureaucrats in the Netherlands: A Delicate Relationship.' Public Administration 84(I), I2I-I46.

Héritier, A., Kerwer, D., Knill, C., Lehmkuhl, D., Teutsch, M., and Douillet, A.-C. (200I). Differential Europe: The European Union Impact on National Policy-making. Lanham, MD: Rowman and Littlefield.

Jacobsson, B., Laegreid, P., and Pedersen, O.K. (2004). Europeanization and Transnational States: Comparing Nordic Central Governments. London: Routledge.

Kassim, H., Menon, A., Peters, B.G., and Wright, V. (eds.). (2000). The National Co-ordination of EU Policy: The Domestic Level. Oxford: Oxford University Press. 
Lægreid, P., Steinthorsson, R.S., and Thorhalsson, B. (2004). Europeanization of Central Government Administration in Nordic States. Journal of Common Market Studies 42(2), 347-369.

LaRue, T. (2006). Agents in Brussels: Delegation and Democracy in the European Union. PhD Dissertation, Umea University Department of Political Science.

Lévi-Strauss, C. (1962). La Pensée Sauvage. Paris: Plon.

March, J.G., and Olsen, J.P. (1989). Rediscovering Institutions. New York: Free Press.

Maynard-Moody, S., and Musheno, M. (2003). Cops, Teachers, Counselors: Stories from the Front Lines of Public Service. Ann Arbor: University of Michigan Press.

Page, E., and Jenkins, W.I. (2005). Policy Bureaucracy. Oxford: Oxford University Press.

Peters, B.G. (200I). The Politics of Bureaucracy ( $5^{\text {th }}$ ed.). New York: Routledge. Raad voor het Openbaar Bestuur (2004). Nationale Coördinatie van EU-Beleid. [National Coördination of EU Policy.] The Hague: ROB.

Richardson, J. (ed.). (2006). European Union: Power and Policy-Making ( $3^{\text {rd }}$ ed.). Abingdon: Routledge.

Savoie, D.J. (2003). Breaking the Bargain: Public Servants, Ministers, and Parliament. Toronto: University of Toronto Press.

Schout, A. (1998). Internal Management of External Relations: The Europeanisation of An Economic Affairs Ministry. Maastricht: EIPA.

Sie Dhian Ho, M., and Van Keulen, M. (2004). 'The Dutch at the Helm Navigating On a Rough Sea: The Netherlands 2004 Presidency of the European Union.' Research and European Issues 34. Paris: Notre Europe.

Slaughter, A.M. (2004). A New World Order. Princeton and Oxford: Princeton University Press.

Smith, J. (2000).'Cultural Aspects of Europeanization: The Case of the Scottish Office.' Public Administration 79(I), I47-I65.

Smith, J. (200I). The Europeanisation of the Scottish office, 1973-1997. Doctoral dissertation, Glasgow Caledonian University.

Thedvall, R. (2006). Eurocrats at Work. (Stockholm Studies in Social Anthropology, 58.) Stockholm: Almund and Wiksell.

Trondal, J. (2002). 'Beyond the EU Membership/Non-Membership Dichotomy? Supranational Identities among National EU Decision-Makers.' Journal of European Public Policy 9(3), 468-487.

Van Schendelen, M.P.C.M. (2003). Machiavelli in Brussels: The Art of Lobbying the EU. Amsterdam: Amsterdam University Press. 